\title{
USING BLOGS IN TEACHING TERTIARY ESL WRITING
}

\author{
Romualdo A. Mabuan \\ Lyceum of the Philippines University \\ E-mail: romualdo.mabuan@lpu.edu.ph
}

APA Citation: Mabuan, R. A. (2018). Using blogs in teaching tertiary ESL writing. English Review: Journal of English Education, 6(2), 1-10. doi: 10.25134/erjee.v6i2.1238.

Received: 14-02-2018

Accepted: 23-04-2018

Published: 01-06-2018

\begin{abstract}
Anchored on the Technological, Pedagogical and Content Knowledge or TPACK Framework (Koehler \& Mishra, 2009) and Substitution, Augmentation, Modification and Redefinition or SAMR Model of Technology Integration into the classroom (Puentedura, 2014), this study investigated a corpus of 58 blog posts written by ESL learners through weblogs. It aimed to determine the views of students on the use of blogs in learning English writing skills and to explore students' feedback on the advantages of blogging as a virtual writing platform. Research participants were 58 freshman university tourism students enrolled at a Study and Thinking Skills class in a private university in Manila, the Philippines during the first semester of the academic year 20172018. Research data drawn from students' blogs, survey questionnaires and focus group discussion revealed that despite accessibility issues due to technological resources, the learners viewed blogging as a viable platform in learning English writing skills because it affords them freedom to express their thoughts, it develops or improves their writing skills, and it allows them to connect and engage with their peers online, inter alia. Pedagogical implications for ESL writing teachers and researchers are offered based on these results.
\end{abstract}

Keywords: Teaching writing, ESL writing, weblogs, blogging, TPACK, SAMR

\section{INTRODUCTION}

The teaching of writing particularly in the context of ESL instruction is rife with challenges, as teachers often face student reluctance, if not resistance, to express their thoughts through writing in English. Viewed as the most difficult English skill (Richards \& Renandya, 2002) and one of the most complex English macro skills to be mastered (Flower \& Hayes, 1980; Tillema, 2012), writing demands learner's ability to construct sentence and paragraph structures that are grammatically correct, syntactically accurate, and semantically appropriate, inter alia. While learning the writing skills may be tedious and grueling among students, it is a necessary skill to possess to be functional, productive and competent in the $21^{\text {st }}$ century, when communication, together with critical thinking, collaboration, and creativity (Partnership for $21^{\text {st }}$ Century Skills, 2006), is a hallmark of personal, social and professional competency.

Cognizant of these social and educational realities, as well as the modern nature of the $21^{\text {st }}$ century learners who have ' $24 / 7 / 365$ fingertip access to technology' (Mabuan, 2017), the $21^{\text {st }}$ century English language educators must ensure that they teach their students with the end-goals in mind (Spady, 1994) by harnessing the myriad of modern technological resources and carefully integrating them into their classroom contexts via varied means such as "substitution, augmentation, modification, and redefinition" (Puentedura, 2014). Following Koehler and Mishra's (2009) Technological, Pedagogical and Content Knowledge (TPACK) Framework, which posits that the modern educator should possess mastery not only in subject matter and pedagogy but also in technological know-how for maximum curriculum delivery, this study explores how Web 2.0 technology, particularly blogging, can be used in the ESL classroom to help facilitate the teaching and learning of writing skills among students.

Blogs (short for "web logs") are free, manipulable, and personalized online websites that look like a journal or diary. Blogs are 
easy-to-use and easy-to-maintain websites which allow a blogger or a blog user to create, edit, and publish written outputs called blog posts into the blogosphere (blog community in the cyberspace) through a blog platform, which is a free web hosting service (Campbell, 2003). Blogs are popular but not necessarily new. They have been existing for 27 years since their introduction into the World Wide Web in 1991 as a mode of sharing information. Early blogs had three primary features - contained links to other areas of interest in the web, commentary on the links, and interactivity and interconnectedness (Li \& Chignell, 2010).

Blogs afford ESL teachers and learners various opportunities. Campbell (2003) claimed that blogs' features such as easy-touse interface, frequent text update, and interactive comment area make them applicable in writing classes. Ferdig and Trammell (2004) posited that blogs are medium for dialogs between bloggers and readers, readers with other readers, and bloggers with other bloggers and their readers, while Nowson (2006) indicated that blogs provide freedom to the blogger to write and publish absolutely anything about everything, at any time in anywhere as long as there is an internet connection. Sun (2010) asserted that blogging might help develop students' writing skills, increase their motivation, and stimulate learner autonomy. Nepomuceno (2011) observed that blogging in the ESL classroom could be an effective alternative writing activity to develop and improve students' writing proficiency. Cequena (2013) found that essay writing through blogging improved her students' writing skills, which also corroborated with the students' positive perception on their peers' constructive feedback on their blog posts. Kitchakarn (2014) reported that his students' writing ability improved through collaborative writing activities in blogging such as commenting, editing and revising blog posts.

Furthermore, Akdag and Ozkan (2017) also found that blogs could be effective tools in improving students' writing skills, enhancing students' enthusiasm in writing, and fostering students' autonomy in writing. Other studies (Saeed, 2009; Wang \& Woo, 2010; Gomez \& McDougald, 2013; Kaupmees, 2015) have suggested that through blogging, students can organize information, post and share written outputs, give and get comments from other students, search information, link to other students' sites, read and evaluate other students' posts, collaborate and learn from one another, exercise learner autonomy, develop confidence, and reinforce motivation. Hence, this paper aims to ascertain the findings of the foregoing studies and to contribute to the growing literature on blogging as applied in ESL writing contexts. Specifically, it aims to answer the following questions:

1. How do students view the use of blogging in an ESL class?

2. What are the affordances of blogging as experienced by the students?

\section{METHOD}

Utilizing a qualitative research design to unravel learners' viewpoints on the use of blogs in the classroom, this study was participated in by 58 freshman university (16 males and 42 females; ages ranged from 16 to 20 years old) enrolled in a Study and Critical Thinking Skills class, majoring in Bachelor of Science in International Travel and Tourism Management in a private tertiary institution in Manila, the Philippines. They have an average English learning experience of 10 years, and their English proficiency levels ranged from lower intermediate to intermediate based on their TOEIC (Test of English for International Communication) scores. The class ran for 1.5 hours with two sessions per week. This study was conducted during the first semester of academic year 2017-2018, from August 7 to September 9, covering five weeks. Free prior informed consent was sought from the participants and their parents.

The Blog Project was announced to the class as a midterm project. Prior to the conduct of the study, participants' "virtual profiles" were checked by identifying the social networking sites that they maintain. The survey revealed that the three most popular social networking sites among the respondents are Facebook (58, 100\%), Twitter (32, $55.17 \%)$, and Instagram (30, 51.72\%). In a 
ENGLISH REVIEW: Journal of English Education Volume 6, Issue 2, June 2018

day, they accessed their social media for at least an hour $(12,24.14 \%)$, more than an hour but less than five hours $(17,29.31 \%)$, and more than five hours $(29,50 \%)$. Their social media activities include posting, reading, and commenting on their 'walls' and on friends' status updates, chatting, uploading photos and videos, and sharing information. Furthermore, when asked whether they have heard about blogs, they responded as follows: No (6, $10.34 \%)$; Yes, but no idea what it is (21, $36.21 \%)$; Yes, but have a slight what it is (20, $34.48 \%)$; and Yes, and have a blog (11, $18.97 \%)$.

Survey questionnaires, focus group discussion, and students' blog posts were utilized to gather research data. Two surveys were administered to the respondents. Prior to the implementing of the project, a pre-project survey questionnaire was administered to the respondents to gather personal information and to determine their exposure to technology particularly social networking sites. The responses were used to organize the project in terms of what blogging platform to utilize, how much blogging the learners should do per week, what topics should be included, and how much background knowledge learners had of blogs. A post-project open-ended survey questionnaire was administered to the participants to determine their perceived advantages and advantages of the blog project as an alternative writing platform.

Prior to the implementation of the Blog Project, the researcher identified the platform or blog site, which would be utilized by the class, taking into consideration Soares' (2008) recommendation that teachers who would like to implement blogging in their classes should have "trial blogs before using the 'real thing' with students, checking if the platform chosen caters for all the wants and needs." The researcher set some basic criteria before deciding on the blog site to be introduced to the class: 1) User-friendliness (i.e., the site must be easily navigation-able and must require only basic technical skills from setting up to publishing so that the students will have more time for blogging), 2) customizability (i.e., the site must contain interesting features for the students such as access to free themes,
p-ISSN 2301-7554, e-ISSN 2541-3643 https://journal.uniku.ac.id/index.php/ERJEE

formats, layouts, and integration of widgets, comment sections, and photo and video blogging), and 3) security (i.e., the site must secure by providing students username and password for blog owner's access, as well as security codes for comment posting and preventing of unsolicited posts or comments). Shortlisted among these platforms based on the set criteria were Blogger (www.blogger.com), Multiply (www.multiply.com), MySpace (www.myspace.com), Tumblr (www.tumblr.com), and WordPress (www.wordpress.com).

Being an active blogger himself for five years, the researcher tested all the shortlisted blog sites and finally decided to use Blogger as the platform for the project. Furthermore, to keep track of students' blog posts without manually visiting every individual blog, the researcher used Bloglines, a web-based service news-feed collector (also called 'aggregator') which enabled him to subscribe to the RSS (Real Simple Syndication or Rich Site Summary) feed of each of the students' blog, allowing him to read all of the students' blogs in one site from any computer connected to the Internet. Upon downloading and installing the notifier, the researcher was alerted whenever the subscriptions have new items to read. This aggregator also helped the researcher organize blogs by students' real names rather than pseudonyms.

Here, the students were encouraged to publish two blog posts per week related to the general topics provided. General weekly topics included the following: Week 1: Personal topics such as hobbies, goals, pet peeves, etc.; Week 2: Educational topics and issues such as the use of social media in the classroom, the $\mathrm{K}$ to 12 system in the Philippines, etc., Week 3: Societal issues such as the new tax reform law (TRAIN Law) in the Philippines, the reinstitutionalization of the Death Penalty Law in the Philippines, Philippine government's War on Drugs campaign (e.g., Tokhang), etc.; Week 4: Global issues such as global warming and climate change, human trafficking, terrorism, etc.; and Week 5: Reflection post covering the students' learning experience in the class' Blog Project. The 


\section{Romualdo A. Mabuan}

Using blogs in teaching tertiary ESL writing

students were reminded to observe formal English writing and avoid text-messaging type of writing, use of emoticons, and colloquialisms.

After the project was completed, 10 students volunteered for a focus group discussion with the researcher to discuss the blog project. Students responded to openended questions exploring their perceptions on the benefits, limitations, and challenges encountered in blogging. These responses were used to validate students' responses in the survey questionnaires. Some of the openended questions asked include the following:

"How would you describe your blogging experience?" "Do you think writing online through blogging helped you improve our English skills particularly writing? If yes, could you cite some of these improvements?" "What did you learn from this blog project?"

"What were the challenges that you encountered while doing the blog project?" "Did you likelenjoy the project? Why or why not?" "How can this project be better?" "Would you continue blogging?"

To explore students' feedback on the use of blogging, their blog posts were collected and quantified, and the survey questionnaire responses were coded and analyzed following Guest, McQueen, and Namey's (2012) Thematic Analysis Framework. Interview results were then qualitatively described to validate these findings.

\section{RESULTS AND DISCUSSION}

Throughout the five-week implementation of the Blog Project, the researcher yielded important data as regards the blogs posted and the feedback of student bloggers on writing online through blogging. In terms of the quantity of blog posts, the 58 participants published 418 blogs online within the duration of five weeks, with an average of 83.6 posts per week. Among these blogs, the maximum number of words is 1,956 , while the least number of words in a blog is 20 . On the average, blogs are composed of 319.67 words. These figures showed the pedagogical viability of blogging as to its impact on motivating learners to express their ideas, emotions, and opinions freely through online writing.

Despite having no rigid guidelines in blogging such as sentence and paragraph structures, style, and word limits, and despite the absence of any evaluative measure or grading system for each of the blog post, it can be observed that students manifested significant interest in writing online through blogging. While this student activity can be attributed to the blogging being introduced as a class midterm project, the newness of blogging may have influenced students' motivation and enthusiasm in writing as seen in the frequency of their posts and the quantity of words for each post. Furthermore, it should also be noted that students did not only use text blogging; they also incorporated photo and video blogging as well as hyperlinking to their classmates' blog sites and other websites. This implies that blogging affords students features that promote students' enthusiasm for writing, creativity, and collaboration. Figure 1 below presents the blog count for each week.

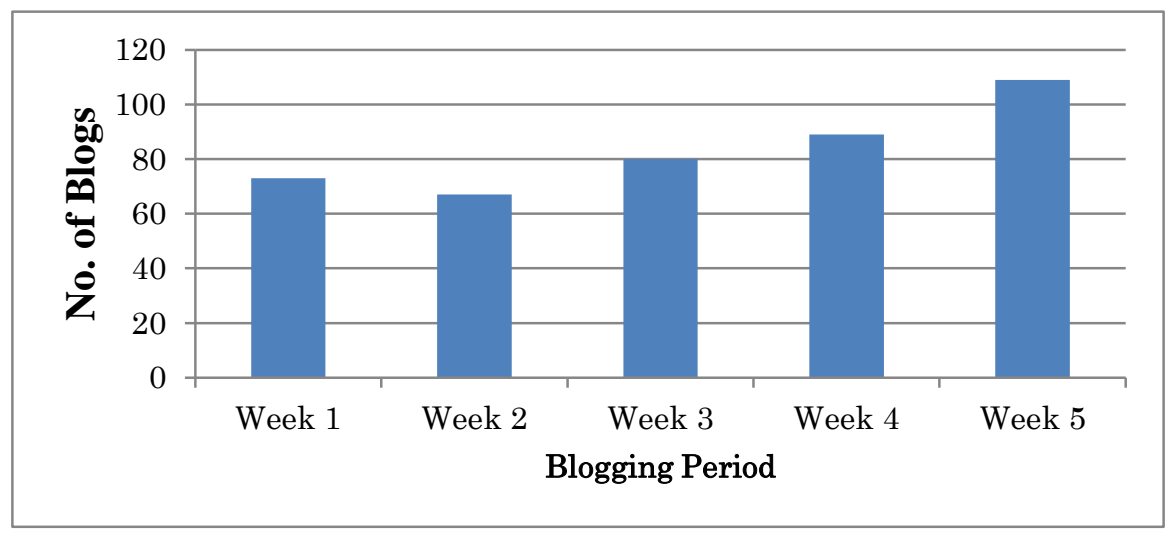

Figure 1. Blog count per week 
ENGLISH REVIEW: Journal of English Education Volume 6, Issue 2, June 2018

This data shows an upward movement from the onset of the project. On the Week 1 of the Blog Project, 73 blogs $(17.46 \%)$ were posted, showing the project's wide acceptance among students, despite some complaints of lack of sufficient knowledge on blogging, having no technological resources like personal computer and internet connection at home, and weak or unstable internet connection. Yet, there was a slight decrease of the number of posts for Week $2(67,16.03 \%)$. This may be due to the busy schedule of the students in preparation for their preliminary examinations, which brought a growing number of school tasks and projects to do. However, after Week 2, a consistent upward trend is remarkably noticeable from Week 3 (80 blog posts, 19.14\%), to Week 4 (89 blog posts, $21.29 \%$ ) and to Week 5 (109 blog posts, $26.08 \%$ ) when it reached its peak. This may be due to the consistent motivation and encouragement given to the students by the teacher, increased learning and adaptability of the technical know-how of blogging, and growing interest of the participants upon seeing their classmates' posts and comments to one another. This strengthens the author's claim that blogging is not merely a writing activity but an avenue for learning new things and for sharing experiences, ideas, and information.

These findings are consistent with the observations of some authors (Yunus, et al.,
p-ISSN 2301-7554, e-ISSN 2541-3643 https://journal.uniku.ac.id/index.php/ERJEE

2013; Okan \& Taraf, 2013; Awada \& Ghaith, 2014) that delineate the pedagogical viability of integrating blogging into writing classes. Furthermore, these findings corroborate with the results of previous studies (Cequena, 2013; Kitchakarn, 2014; Akdag \& Ozkan, 2017) indicating the educational benefits of using blogs in the English writing classroom to develop and enhance students' writing skills.

\section{Learner-perceived advantages of the blog project}

Students' survey and interview results revealed that all of them "enjoyed" the Blog Project overall. When being asked about the benefits of the project, the reasons why they enjoyed blogging, and what they learned from the Blog Project, students reported a variety of responses. Of the total 94 answers, 32 (34.04 $\%$ ) pointed on the affordance of blogging in providing students the freedom to express their ideas and opinions on different topics. Fourteen responses (14.89\%) suggested that blogging improved students' writing skills, while $11(11.7 \%)$ underscored the social connection that blogging has established among the students in the virtual space. Table 1 lists all of the students' responses showing the benefits of blogging, while Table 2 presents students' avowals supporting their viewpoints.

Table 1. Learner-perceived advantages of blogging

\begin{tabular}{lll}
\hline Blogging... & $\mathbf{f}$ & \% \\
\hline promotes freedom and confidence to express and share one's & 32 & 34.04 \\
feelings, ideas, and opinions on certain topics and issues & & \\
improves writing skills & 14 & 14.89 \\
facilitates peer online interaction and engagement & 11 & 11.70 \\
increases societal awareness & 8 & 8.51 \\
develops understanding of oneself and others & 7 & 7.45 \\
allows learning and use of new vocabulary & 6 & 6.38 \\
facilitates grammar practice & 6 & 6.38 \\
allows practice in technology & 4 & 4.26 \\
promotes critical thinking & 4 & 4.26 \\
allows learning of new ideas & 2 & 2.13 \\
Total & $\mathbf{9 4}$ & $\mathbf{1 0 0}$ \\
\hline
\end{tabular}


Romualdo A. Mabuan

Using blogs in teaching tertiary ESL writing

Table 2. Students' avowals

\begin{tabular}{l}
\hline Perceived benefits of blogging \\
\hline Promotes freedom and confidence \\
to express and share one's \\
feelings, ideas, and opinions on \\
certain topics and issues
\end{tabular}

Interview transcripts and reflections showing students' perceptions on the benefits of blogging

Through blogging, I learned to express my ideas and opinion on different topics. (S9-M-18)

This blog project develops my self-confidence in posting personal opinions and experiences. (S13-F-16)

The Blog Project helps me to express my ideas through the cyber world. I am free to share with others what I really feel about something or someone I want to talk about. (S2-F-20).

Improves writing skills

I believe my written communication skill improved while I expressed myself in this blog project because I learned how to write in different styles to make my blogs interesting for my classmates. (S30-F-18)

It forced me to write... at first I thought it was very boring, but as I continued to blog, I learned how to love writing. It's interesting and helpful. (S17-M-16)

Facilitates online peer interaction and engagement

It helped us to interact with our classmates by reading and leaving comments on each other's blogs. (S26-F-17)

Increases societal awareness

It helped me widen and deepen my thoughts about the things around me. (S12$M-17)$

I was able to know the issues here in the Philippines \& around the world. (S1$M-18)$

By researching for my own topics and reading my classmates' blogs, I learned more about the different situations in our society. (S40-F-17)

This project let us see the world in a broader way. (S55-M-18)

Develops understanding of oneself and others

This project made me know others well. It helped me reach out to people for them to understand me for who I am. (S10-M-16)

In just a click, people around me could have piece of me and of course, I did that that in the same way to their blog posts in order for me to know their part. (S34-F-17)

Allows learning and using new vocabulary

Because of this blog, I learned to research and check the spelling of words first before I published them. I also encountered new words that I didn't know. (S56-F-16)

I have been more creative in picking the best words for my blogs. (S42-M-17)

Facilitates grammar practice

I was very careful with my grammar and vocabulary, and even spelling. Before posting my blog, I made it sure that I didn't have errors, because my classmates and teacher would read my blogs. (S11-M-18)

I think my grammar improved because my classmate constantly checked my sentences. I thank her for that. (S38-M-17)

This project also helped me detect the errors in grammar of classmates as well as correct them and vice versa. (S29-F-17)

This blog project enhanced my English grammar on how to create and combine correct sentences using the English language. I was able to write long sentences. (S20-F-16)

Allows practice in technology This blog project helped us to maximize our gadgets and technologies in a better way. (S18-M-17)

I was able to use this technology in a useful and sensible way. (S45-F-18)

Promotes critical thinking

Our reasoning and judgment were practiced in commenting on the societal and global issues. (S51-M-20)

Consistent with the findings of several studies (Blackmore-Squires, 2010; Delgado \& McDougald, 2013; Kaupmees, 2015; Ozdemir \& Aydin, 2015), this study found that the most valued feature of blogging among students is the 'freedom space' that it affords them so that they could express freely through writing their perspectives on certain topics and issues. This finding suggests that blogging can be an alternative platform to traditional in-class writing where students can stage their thoughts and voice out their minds anytime and anywhere at the convenience of virtual writing - a technological affordance that could be a viable solution to limited classroom communication engagement particularly in 
ENGLISH REVIEW: Journal of English Education Volume 6, Issue 2, June 2018

large classes. Furthermore, this freedom space allows students to strike a balance between the rigorous and structured formal academic writing in the classroom and the more relaxed and less structured blogging where students can express their ideas and arguments and experiment with their writing styles (Oliver, 2016).

Another significant finding in this study points to the educational benefit of blogging in facilitating the learning of English writing skills among students. This observation corroborates with the established literature on blogging in writing classes (Said et al., 2013; Karlsson, 2014; Kitchakarn, 2014; Akdag \& Ozkan, 2017) demonstrating the pedagogical potential of blogging in developing and enhancing students' writing skills. With the excitement of trying a new mode of communication and connecting with a virtual audience beyond the confines of time and space in the traditional writing classroom, students were motivated and thrilled to see their ideas published on the web instantaneously and accessed by their classmates and teacher - a departure from the time-constrained traditional paper-and-pen inclass writing activity. Moreover, students' digital competence (Ferrari, 2013) may be developed as they can focus beyond writing content; they can integrate other media such as images, audios and videos and hyperlink websites. Likewise, they can develop skills in podcasting (Audacity), video blogging or vlogging (YouTube), and creating a presentation (SlideShare) (Dyer, 2017). This finding embodies Puentedura's (2014) notion on 'redefinition' in technology integration into the classroom which posits that technology (i.e., blogging) allows learners to perform tasks previously inconceivable and provides them a new learning experience.

Validating the findings of recent studies

(Chan \& Cmor, 2009; Zinger \& Sinclair, 2013; Dyer, 2017), this study also found out that blogging can facilitate peer-to-peer engagement through comments and feedback among their blog posts. Because students were required to read and comment on at least five blog posts of their classmates every week, they were aware that they had audience or readers.
p-ISSN 2301-7554, e-ISSN 2541-3643

https://journal.uniku.ac.id/index.php/ERJEE

This practice motivated students to write blog posts regularly and prompted them to observe correct grammar usage and proper vocabulary in their sentence constructions, considering that their blog posts would be read by audiences. By reading their classmates' blog posts, students learned new ideas from one another; and by commenting on their classmates' blog posts, they became active collaborators in the exchange of information over the web.

However, despite the positive feedback towards blogging in the class, students also reported challenges and limitations, which include lack of technological resources such as unavailability of internet-connected electronic devices such as computers, laptops, tablets or mobile phones at home, as well as inaccessibility to stable internet connection. For instance, one student shared, "We don't have a computer with internet at home, so I had to go to a computer shop just to write and publish my blogs" (S16-F-18). Another student complained, "The Wi-Fi connection in our campus is very weak, so it usually took me a long time to post my blog... it's time consuming and frustrating sometimes..." (S57-M-18). Learners' feedback such as these have important implications on the applicability of blogging in the classroom; hence, teachers should consider significant factors that may affect the successful integration of blogging into their classes such as the availability of infrastructure, technological resources, learners' digital readiness, appropriacy to the curriculum, class design, etc.

\section{CONCLUSION}

This study explored the pedagogical viability of integrating blogging into an ESL class in a private university setting in urban Manila, the Philippines. Findings drawn from survey questionnaires and focus group discussion revealed that, in general, students viewed blogging as a beneficial platform in helping them practice their English writing skills, expressing their thoughts and ideas freely, and facilitating online peer engagement, among others. These findings corroborate with the results of recent studies (Kitchakarn, 2014; 
Kaupmees, 2015; Oliver, 2016; Akdag \& Ozkan, 2017; Hernandez, Amarles, \& Raymundo, 2017) that underscored the applicability of integrating blogging into writing classes as afforded by its accessibility, flexibility and interactivity features, to name a few. However, limitations to technological access such as availability of internet-capable devices and stable internet connection remain to be significant hurdles to the successful use of blogging in any classroom; hence, this should implicate educators to consider their own contexts and to decide cautiously whether or not their institutions and classes are ready for this digital innovation.

Finally, certain limitations of this study must be noted: First, this study was conducted in only one freshman class in a private university setting for five weeks; thus, the findings of this study may limit their external validity and generalizability to other contexts. Second, because of its exploratory nature, the blogging activity in this class did not strictly follow a writing rubric that might have influenced students' blog posts' word count, paragraph development patterns, writing styles, language use, and other conventions. Hence, future studies may explore other classroom settings and levels, apply specific writing guidelines in blogging, and investigate students' blogs both qualitatively and quantitatively.

\section{REFERENCES}

Akdag, E., \& Ozkan, Y. (2017). Enhancing writing skills of EFL learners through blogging. The Reading Matrix: An International Online Journal, 17(2), 79-95.

Awada, G., \& Ghaith, G. (2014). Effect of using the blog educational tool on writing achievement and motivation for legal writing. International Journal of Education and Research, 2(12), 371-388.

Blackmore-Squires, S. (2010). An investigation into the use of a blog as a tool to improve writing in the second language classroom. Unpublished MA thesis. University of Manchester, UK.

Campbell, A. P. (2003). Weblogs for use with ESL classes. The Internet TESL Journal, 9(2).

Cequena, M. (2013). Does blogging facilitate the development of students' writing skills? Philippine ESL Journal, 10, 126-147.

Chan, C., \& Cmor, D. (2009). Blogging toward information literacy: Engaging students and facilitating peer learning. Reference Services Review, 37(4), 395-407.

Dyer, K. (2017). The benefits of blogging for student life. Retrieved from

http://www.presence.io/blog/why-blog-thebenefits-of-blogging-for-student-life/.

Ferdig, R., \& Trammell, K. (2004). Content delivery in the 'blogsphere'. Retrieved from http://defiant.corban.edu/jjohnson/pages/teaching/ bloggingblogosphere.pdf.

Ferrari, A. (2013). DIGCOMP: A framework for developing and understanding digital competence in Europe. Luxembourg: Publications Office of the European Union.

Flower, L. S., \& Hayes, J. R. (1980). The dynamics of composing, making plans and juggling constraints. In L. W. Gregg, \& E. R. Steinberg (Eds.), Cognitive process in writing (pp. 31-50). Hillsdale, N. J.: Lawrence Erlbaum Associates.

Gomez, O., \& McDougald, J. (2013). Developing writing through blogs and peer feedback. Ikala, revista de language y cultura, 18(3), 45-61.

Guest, G., McQueen, K., \& Namey, E. (2012). Applied thematic analysis. Thousand Oaks, California: Sage Publications.

Karlsson, A. (2014). How can blogging in foreign language education improve pupils' writing skills? A research synthesis. Unpublished MA thesis. Malmo University, Sweden.

Kaupmees, H. (2015). Students' perceptions of and attitudes toward using blogging in upper intermediate EFL classes. Unpublished MA dissertation. University of Tartu, Estonia.

Kitchakarn, O. (2014). Developing writing abilities of EFL students through blogging. Turkish Online Journal of Distance Education, 15(4), 34-47.

Koehler, M. J., \& Mishra, P. (2009). What is technological pedagogical content knowledge? Contemporary Issues in Technology and Teacher Education, 9(1), 60-70.

Li, J., \& Chignell, M. (2010). Birds of a feather: How personality influences blog writing and reading. International Journal of Human Computer Studies, 68(9), 589-602.

Mabuan, R. A. (2017). Developing ESL/EFL learners' public speaking skills through Pecha Kucha presentations. English Review: Journal of English Education, 6(1), 1-10. DOI: 10.25134/erjee.v6i1.765.

Nepomuceno, M. (2011). Writing online: Using blogs as an alternative writing activity in tertiary ESL classes. TESOL Journal, 5, 92-105.

Nowson, S. (2006). The language of weblogs: A study of genre and individual differences. Unpublished $\mathrm{Ph} . \mathrm{D}$. thesis. Institute for Communicating and Collaborative Systems, School of Informatics, University of Edinburgh. (Online). Retrieved from http://www.era.lib.ed.ac.uk/bitstream/1842/1113/1/ thesis.pdf. 
ENGLISH REVIEW: Journal of English Education

Volume 6, Issue 2, June 2018

Okan, Z., \& Taraf, U. H. (2013). The use of blogs in second language teacher education. ProcediaSocial and Behavioral Sciences, 83, 282-289.

Oliver, K. H. (2016). Teaching with blogs. Retrieved from https://cft.vanderbilt.edu/teaching-withblogs/.

Ozdemir, E., \& Aydin, S. (2015). The effects of blogging on EFL writing achievement. ProcediaSocial and Behavioral Sciences, 199, 372-380.

Partnership for $21^{\text {st }}$ Century Skills. (2006). A state leader's action guide to $21^{\text {st }}$ century skills: A new vision for education. Tuczon, AZ: Partnership for $21^{\text {st }}$ Century Skills.

Puentedura, R. (2014). Learning technology and the SAMR model: Goals, processes, and practice.

Retrieved from http://www.hippasus.com/rrpweblog/archives/201 4/06/29/ LearningTechnologySAMRModel.pdf.

Richards, J. C., \& Renandya, W. A. (2002). Methodology in language teaching: An anthology of current practice. Cambridge: Cambridge University Press.

Saeed, N. (2009). Emerging web technologies in higher education: A case of incorporating Blogs, Podcasts and social bookmarks in a web programming course based on students' learning styles and technology preferences. Retrieved from http://www.ifets.info/journals/12_4/9.pdf.
p-ISSN 2301-7554, e-ISSN 2541-3643

https://journal.uniku.ac.id/index.php/ERJEE

Said, N. E. M., Yunus, M., Doring, L. K., Asmi, A., Aqilah, F., \& Li, L. K. S. (2013). Blogging to enhance writing skills: A survey of students' perception and attitude. Asian Social Science, 9(16), 95-101.

Spady, W. G. (1994). Outcome-based education: Critical issues and answers. Arlington, VA: American Association of School Administrators.

Sun, Y. C. (2010). Extensive writing in foreignlanguage classrooms: A blogging approach. Innovations in Education and Teaching International, 47(3), 327-339.

Tillema, M. (2012). Writing in first and second language: Empirical studies on text quality and writing processes. The Netherlands: LOT.

Wang, Q., \& Woo, H. (2010). Investigating students' critical thinking in weblogs: An exploratory study in a Singapore secondary school. Asia Pacific Education Review, 11(4), 541-551.

Yunus, M. M., Tuan, J. L. K., \& Salehi, H. (2013). Using blogs to promote writing skill in ESL classroom. Recent Advances in Educational Technology. Proceedings of the $4^{\text {th }}$ International Conference on Education and Educational Technologies (EET '13), 109-113.

Zinger, L., \& Sinclair, A. (2013). Using blogs to enhance student engagement and learning in the health sciences. Contemporary Issues in Education Research, 6(3), 349-352. 


\section{Romualdo A. Mabuan}

Using blogs in teaching tertiary ESL writing 